\title{
Effect of Working Capital Liquidity on the Financial Performance of Hire Purchase Companies in Kenya
}

\author{
Morris Irungu Kariuki \\ Lecturer, Department of Finance and Accounting, University of Nairobi, Kenya
}

\begin{abstract}
The theory of working capital management contends that if working capital is managed according to prescriptive theory then it would be expected that businesses would invest in working capital, finance working capital, monitor factors that influence working capital, manage cash, accounts receivable, inventory, accounts payable, the cash conversion cycle and measure the performance by ratio analysis to ensure that long term assets are utilized effectively and efficiently. This study examined the liquidity and the cash conversion cycle of 6 hire purchase companies in Kenya. The methodology involved a descriptive research design. The study used secondary data collected by use of a financial data schedule which was processed using SPSS version 21. The study found that the ratio of working capital to total asset was $27 \%$. The other main conclusion is that working capital significantly explains financial performance of the hire purchase companies. The finds of the study are beneficial to the corporate decision makers, investors, financial institutions, government and other stakeholders in Kenya as well as other countries of the world.
\end{abstract}

Keywords: days of receivable, days of payable, days of sales, cash conversion cycle, current ratio, quick ratio.

\section{Introduction}

The field of financial management remains of prime concern for financial theorist and business practitioners. For the former, it gives excellent opportunities for developing a practical positive theory based on a rational and quantitative framework. For the latter, the process of efficient allocation of funds probably constitutes the most vital decision taken by management, since the non-current assets and current assets have to be combined in optimum proportions [1]. [2] points out that financial management can be divided into long-term financial management and short-term financial management. Long-term financial management involves cash flow decisions over the extended period of time i.e. over one year. Short-term financial management involves cash flow decisions within a year. Short-term financial management is also referred to as working capital management.

As stated by [3], [4] and [5] working capital management is concerned with the problem that arise in attempting to manage working capital i.e. current assets, the current liabilities and the inter relationship that exists between them. The basic goal of working capital management is to manage the firm's current assets and liabilities so that the satisfactory level of working capital is maintained. If the firm cannot maintain a satisfactory level of working capital, it is likely to become insolvent and may be forced into bankruptcy. A margin of safety is said to be maintained when currents assets are enough to cover the current liabilities. This eliminates the risk of inability to meet short-term obligations on the one hand and avoiding excessive investment in these assets on the other hand. Therefore, working capital should be neither more nor less, but just adequate. Excessive levels of working capital can lead to firm realizing a sub-standard return on investment because the firm's profitability is affected. On the other hand, a low level of working capital may lead to low liquidity and stock out, resulting in difficulties in maintaining smooth operations. The main purpose of any firm is maximization of profits. But, maintaining liquidity of the firm is an important objective.

A firm is required to maintain a balance between liquidity and profitability while conducting its day to day operations. Liquidity is a pre-condition to ensure that companies are able to meet their short-term obligations. The importance of working capital as an indicator of continuing financial health cannot be overemphasized in view of its crucial role within the business. However, to much focus on liquidity will be at the expense of profitability. Manager usual have dilemma of achieving desired trade off between liquidity and profitability in order to maximize the value of the firm [6]. Cash management is one of the key areas of working capital management. Apart from the fact that it is the most liquid asset, cash is the common denominator to which all current assets; that is receivables and inventory get eventually converted into cash. Cash is the oil that lubricates the ever-turning wheels of business: without it the process grinds to a stop [7]. Accounts receivables management results from credit sales. The purpose of credit sales is to stimulate sales in orders to expand market share and if possible enhance production capacity efficiency. Credit sales create customers who have not yet made payment for good or services, which the firm had provided. The objective of debtors' management is to minimize the time lapse between completion of sales and receipt of payment [7]. 
Inventory management for purchasing, production and marketing of stock should minimize the total costs of handling, carrying and financing inventory. The manner in which inventory is managed affects the levels and structures of raw materials, work in progress and finished goods needed to sustain efficient operations and sales. Any change introduced by management to alter the absolute levels of inventory held will have a direct impact on working capital [7]. Account payable management refers to how current liabilities are managed. The decision to make use of suppliers' credit should be assessed carefully, in terms of alternative sources of finance, discount, credit limit, etc. Once suppliers' credit has been taken, it is important to investigate the extent to which a company can stretch account payable without jeopardizing its credit status with suppliers [7]. Working capital management is quite complex and requires careful planning. Moreover, some very difficult forecasting problems are involved: sales, purchases and cash flows must be estimated into the foreseeable future, in the face of uncertainty. Working capital management is basically related to the question of profitability versus liquidity and related risks. If the firm wants to increase its profitability, the risk will definitely increase and vice versa. The extent to which profits can be earned is dependent upon the magnitude of sales. Sales are necessary for earning profits. However, sales do not convert into cash instantly since there is time lag between sale of goods and receipt of cash. Working capital management affects the profitability and liquidity of the firm which are inversely proportional to each other, hence proper balance should be maintained [8]. [9] states, a firm that is unable to survive will be incapable of satisfying the aims of its stakeholders. Profitability is the ultimate objective of any profit making organization. Profit over the long term is the clearest indication of a firm ability to satisfy the principal claims and desires of stakeholders such employees, stockholders, suppliers, governments, etc.

\section{Statement of the Problem}

The need to maintain adequate working capital can hardly be questioned. The flow of funds like blood circulation is very necessary to maintain business. If it becomes weak, the business can hardly prosper and survive. Working capital starvation is generally credited as a major cause of businesses failure [6]. According to [10] a large number of business that fail are due to inability of financial managers to plan and control current assets and current liabilities of their respective companies. To make the situation worse, there is evidence that small and medium businesses are not very good at managing their working capital. In a study done by [11] in Iran the ratio of accounts payable was $8 \%$ as compared with total assets and the ratio of accounts receivable and inventory as compared with total asset was $17 \%$ and $20 \%$ respectively. Therefore, the amounts of money invested in working capital are often substantial compared to the total assets employed and so it is vital that these amounts are used in an efficient and effective way. [12] show the importance of working capital management by giving an example of two American supermarket; Wal-mart and Kmart which had comparable capital structure in 1994 but Kmart went bankrupt mainly because of poor working capital management.

In Kenya a number of public and private companies among them Uchumi Supermarkets, Invesco Assurance, Discount Securities, Standard Assurance, Pan Paper Mills, Kenya Planters Co-operative Union, Ngenye Kariuki Stockbrokers and Hutchings Beimer have undergone creditors' statutory management [13]. When businesses close due to such failures, the suppliers of capital, investors and creditors, as well as management and employees are severely affected. Consistent with Edward Altman's financial distress prediction model, [13] arrived at accurate prediction. They conclude that these failures arise when the money coming into the company from sales is not enough to cover the costs of production. It is therefore very important to have the money to be able to pay debts when they fall due not simply generating enough revenue during a year to cover costs[14]. This means good working capital management is important in organizations including hire purchase companies. The research problem therefore necessitated the study on liquidity position of hire purchase companies in Kenya.

\section{Objective of the Study}

The general objective of the study is to determine the liquidity position of the hire purchase companies in Kenya Specific objectives of the study included;

1. To examine the liquidity of the hire purchase companies in Kenya.

2.To examine the Cash Conversion Cycle of the hire purchase companies in Kenya.

3.To assess the effect of working capital liquidity on the financial performance of hire purchase companies in Kenya

\section{Research Questions}

The study sought to answer the following questions:-

1. What is the liquidity position of the hire purchase companies in Kenya?

2. What is the average, minimum and maximum Cash Conversion Cycle of the hire purchase industry in Kenya? 3. What is the effect of working capital liquidity on the financial performance of hire purchase companies in Kenya? 


\section{Review of Related Literatures}

The exact trade off between profitability and risk depends largely on the decision makers' attitude towards risk [15]. They continue to state that before deciding on the appropriate level of working capital, the management of the firm should evaluate the trade off between expected profitability and the risk that it may be unable to meet its financial obligations. Profitability is measured by the rate of return on total assets and the risk that a firm will encounter financial difficulties is related to the firm's net working capital position. All other aspects the same, the lower the level of liquid assets, the greater would be the risk of being unable to meet current obligations. This creates the risk defined as the probability of technical insolvency. This occur whenever the assets of a firm are less than the liabilities and hence unable to meet its cash obligations. The risk of running out of cash can be reduced by maintaining a high proportion of liquid assets. However, there is a cost involved. This cost is the profit foregone on the investment of these funds in other assets. [15] defines cash conversion cycles as the time between cash disbursement and cash collection i.e. operating cycle less account payable period. To estimate this conversion cycle the firm need to determine how long it takes each non-cash operating account i.e. account receivable, inventory and account payable to be converted to cash, as shown in figure below.

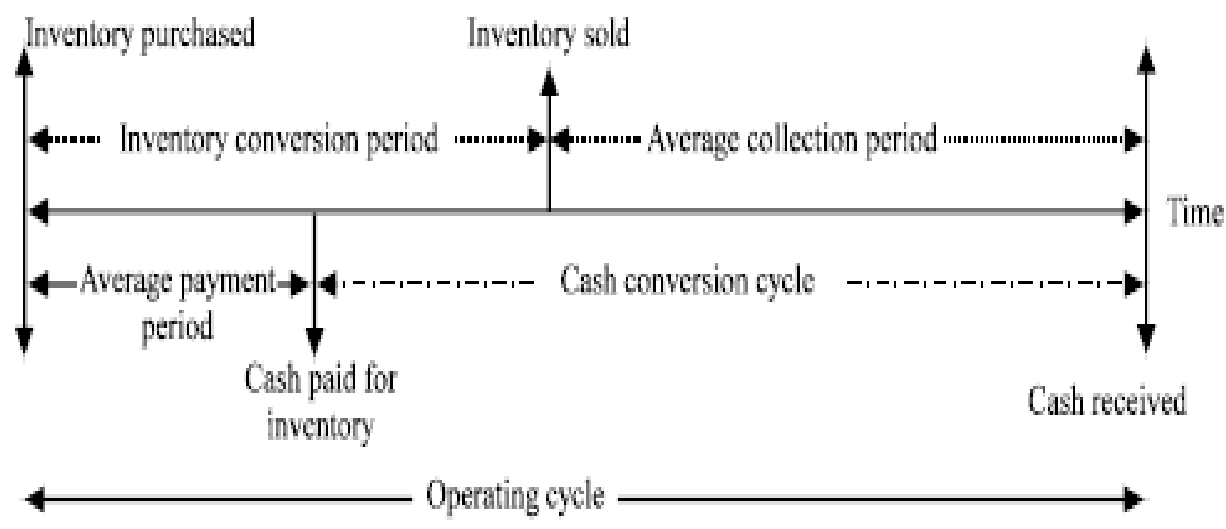

Figure 1: Operating and cash conversion cycles[15]

Good evidence of how important working capital management is for companies has been provided by [12]. They show that although Wal-Mart and Kmart had comparable capital structure in 1994, Kmart went bankrupt mainly because of poor working capital management; Kmart had a cash conversion cycles of about 61 days whereas WAl-Mart had a shorter cash conversion cycles of 40 days. Consequently, Kmart faced an extra US \$ 193.3 millions per year financial costs arising from longer cash conversion cycles that was difficult to sustain. In a study by [16] on British American Tobacco Bangladesh Company Ltd, he found the liquidity position of the company is very much satisfactory due to good turnover of current assets, inventory debtors and cash balances. The company enjoys good facility of cash credit and other working capital loan from different commercial banks. A similar study was done by [17] who used financial data of four Indian private companies dealing with steel production. They found that a liquidity problem was accountable for poor capacity, underutilization and poor consumption and that there exist a relationship between liquidity and profitability indicators.

\section{Methodology}

The objectives of this study are to examine liquidity of 19 hire purchase limited companies in Kenya. The target populations of 19 comprise hire purchase companies licensed under the Hire Purchase Act, Law of Kenya and were members of Hire Purchase Retailers Association of Kenya (HPRAK). Since the total membership of HPRAK is small, a census of 19 companies was done. The 19 companies are all headquartered in Nairobi. To achieve the study objectives secondary data were collected. The Heads of finance function were mainly targeted as respondents since they are routinely in charge of working capital decisions. Secondary data was collected by use of a financial data schedule. Data was extracted from the audited financial statements covering the six financial years from 2005/6 to 2010/11. The income statements, balance sheet, cash flow and the note to the accounts were specifically used. The population consisted 19 companies. Since one firm was used in the pilot study, the financial data schedules were sent to 18 companies in January, 2012. Data preparation involved editing and coding the raw data. Micro Soft Excel and Financial ratios were used to analyze the data collected. Financial ratios were employed because ratios can be used to assess the working capital management strengths and weaknesses of companies [6]. Finally, the data was posted and analysed by SPSS version 21. Descriptive analysis was used to describe the liquidity in the form of minimum, maximum values, mean, standard deviation and coefficient of variation $(\mathrm{CV})$. Finally correlation and multiple regression analysis was done. 
The following regression model was used

$Y=\beta_{0}+\beta_{1} X_{1}+\beta_{2} X_{2}+\beta_{3} X_{3}+\beta_{4} X_{4}+\beta_{5} X_{5}+\varepsilon_{i}$

Where; $\mathrm{Y}=$ return on assets

$\mathrm{X}_{1}=$ quick acid ratio

$\mathrm{X}_{2}=$ current acid ratio

$\mathrm{X}_{3}=$ accounts receivable turnover

$\mathrm{X} 4=$ inventory turnover

$\mathrm{X}_{5}=$ accounts payable turnover

$\beta_{0}=$ the return on asset in the absence of any influence by liquidity.

$\beta_{1}$ to $\beta_{5}$ are the coefficients of liquidity ratios

\section{Study Results}

Out of 18 financial data schedules that were distributed to the hire purchase companies, only 6 financial data schedules were returned filled with data. This represents a response rate of $33.33 \%$. The response rate was considered enough [13]. The study yielded 34 data points since one data schedule provided data for four years. According to [18], at least 30 data point are required to inferential statistics.

Table 1: Descriptive statistics based on the ratio between current assets to total assets

\begin{tabular}{|l|l|l|l|l|l|l|l|}
\hline Firms & A & B & C & D & E & F & Average \\
\hline Minimum & 73.97 & 72.06 & 97.42 & 87.52 & 58.05 & 61.90 & 75.15 \\
\hline Maximum & 85.67 & 77.37 & 98.80 & 93.98 & 72.48 & 67.33 & 82.61 \\
\hline Mean & 81.23 & 75.64 & 98.16 & 91.28 & 62.44 & 64.32 & 78.80 \\
\hline Std Deviation & 9.81 & 4.39 & 1.36 & 5.02 & 11.10 & 3.93 & 5.93 \\
\hline CV & 12.08 & 5.80 & 1.39 & 5.50 & 17.78 & 6.14 & 8.11 \\
\hline
\end{tabular}

Table 1 shows that the mean proportion of current asset of the total asset is $78.80 \%$. This means that current assets are a significant component of working capital and its good management cannot be overemphasized. Companies A, C and D have current asset proportions greater than the average. Companies A and $\mathrm{E}$ maintained a higher variability compared to the average.

Table 2:Descriptive statistics based on the ratio between current liabilities to total assets

\begin{tabular}{|l|l|l|l|l|l|l|l|}
\hline Firms & A & B & C & D & E & F & Average \\
\hline Minimum & 32.95 & 79.70 & 76.13 & 42.87 & 64.67 & 28.73 & 54.17 \\
\hline Maximum & 46.27 & 99.77 & 100.96 & 81.61 & 69.62 & 92.14 & 81.73 \\
\hline Mean & 38.36 & 92.21 & 88.35 & 52.46 & 67.62 & 57.79 & 66.13 \\
\hline Std Deviation & 11.15 & 16.81 & 23.21 & 32.34 & 3.72 & 46.53 & 22.29 \\
\hline CV & 29.06 & 18.23 & 26.27 & 61.64 & 5.50 & 80.52 & 36.87 \\
\hline
\end{tabular}

Table 2 shows that the mean proportion of current liabilities to the total asset is $66.13 \%$. This means that current liabilities are a significant component of working capital and their good management cannot be overemphasized. Companies B, C and E have current liabilities proportions greater than the average. While $\mathrm{F}$ had the highest variability compared with the average.

Table 3:Descriptive statistics based on the ratio between working capital to total assets

\begin{tabular}{|l|l|l|l|l|l|l|l|}
\hline Firms & A & B & C & D & E & F & Average \\
\hline Minimum & 0.38 & 0.00 & $(0.01)$ & 0.16 & 0.18 & 0.05 & 0.13 \\
\hline Maximum & 0.49 & 0.15 & 0.23 & 0.54 & 0.22 & 0.48 & 0.35 \\
\hline Mean & 0.43 & 0.06 & 0.11 & 0.43 & 0.20 & 0.27 & 0.25 \\
\hline Std Deviation & 0.09 & 0.13 & 0.23 & 0.31 & 0.03 & 0.31 & 0.18 \\
\hline CV & 21.82 & 216.63 & 199.6 & 70.65 & 14.73 & 116.12 & 106.59 \\
\hline
\end{tabular}

Table 3 shows that the mean proportion of working capital to the total asset is $27 \%$. This means that working capital is a significant component of total assets and its good management cannot be overemphasized. Half the companies have working capital proportions greater than the average while the half had a higher variability than the average.

Table 4:Descriptive statistics based on the ratio between inventory to current assets

\begin{tabular}{|l|l|l|l|l|l|l|l|}
\hline Firms & A & B & C & D & E & F & Average \\
\hline Minimum & 26.57 & 50.73 & 28.83 & 28.88 & 23.49 & 13.21 & 28.62 \\
\hline Maximum & 46.84 & 70.96 & 40.69 & 56.20 & 34.93 & 25.30 & 45.82 \\
\hline Mean & 33.13 & 57.43 & 32.03 & 36.64 & 31.19 & 20.32 & 35.12 \\
\hline Std Deviation & 17.7 & 17.16 & 11.41 & 22.01 & 8.82 & 8.71 & 14.30 \\
\hline CV & 53.42 & 29.88 & 35.62 & 60.04 & 28.29 & 42.89 & 41.69 \\
\hline
\end{tabular}

DOI: $10.9790 / 5933-0801015059 \quad$ www.iosrjournals.org 
Table 4 shows that the mean proportion of inventory of the current assets is $35.12 \%$. This means that inventory is a significant component of current assets and its good management cannot be overemphasized. Companies B and $\mathrm{D}$ have inventory levels greater than the industries average. Half the companies maintained low variability compared to the average.

Table 5:Descriptive statistics based on the ratio between accounts receivable to current assets

\begin{tabular}{|l|l|l|l|l|l|l|l|}
\hline Firms & A & B & C & D & E & F & Average \\
\hline Minimum & 41.45 & 31.64 & 52.83 & 35.92 & 68.75 & 60.45 & 48.51 \\
\hline Maximum & 66.01 & 67.75 & 68.44 & 76.14 & 99.98 & 73.35 & 75.28 \\
\hline Mean & 57.76 & 51.68 & 60.19 & 52.10 & 85.01 & 65.67 & 62.07 \\
\hline Std Deviation & 21.32 & 31.44 & 11.29 & 29.96 & 22.31 & 9.72 & 21.00 \\
\hline CV & 36.91 & 60.83 & 18.76 & 57.50 & 26.24 & 14.80 & 35.84 \\
\hline
\end{tabular}

Table 5 shows that the mean proportion of accounts receivables to current assets is $62.07 \%$. This means that accounts receivables is a significant component of current assets and its good management cannot be overemphasized. Companies $\mathrm{E}$ and $\mathrm{F}$ have inventory levels greater than the average. While A, B and D have a higher variability than the average.

Table 6: Descriptive statistics based on current ratio

\begin{tabular}{|l|l|l|l|l|l|l|l|}
\hline Firms & A & B & C & D & E & F & Average \\
\hline Minimum & 1.82 & 1.00 & 0.99 & 1.23 & 1.44 & 1.09 & 1.00 \\
\hline Maximum & 2.47 & 1.25 & 1.31 & 2.33 & 1.55 & 3.48 & 3.48 \\
\hline Mean & 2.14 & 1.08 & 1.13 & 1.91 & 1.48 & 1.73 & 1.63 \\
\hline Std Deviation & 0.49 & 0.21 & 0.31 & 0.91 & 0.08 & 1.92 & 0.61 \\
\hline CV & 23.06 & 19.41 & 27.49 & 47.81 & 5.60 & 110.85 & 39.04 \\
\hline
\end{tabular}

Current ratio is a measure of general liquidity and is most widely used to make the analysis of shortterm liquidity of the firm. A relatively high current ratio is an indication that the firm has good liquidity and has the ability to pay its current obligations when they become due. Table 6 shows that the average current ratio for companies A, D and F are satisfactory because they are higher than average. The current ratio of A compares favorably with the ideal ratio of 2:1. This indicates A was able to meet its obligation during the period of study. The current ratio of the other companies $\mathrm{B}, \mathrm{C} \mathrm{D}, \mathrm{E}$ and $\mathrm{F}$ are poor because the current ratio is lower than the ideal ratio. This indicates that they may have had difficulties meeting their obligations during the study period. The standard deviations for firms D and F are higher than the average. Greater variability in the Current ratio indicates improper management of funds because excess liquid funds could have been used for other investments purposes thereby enhancing the growth of the companies.

Quick ratio is a more rigorous test of liquidity than current ratio. A high quick ratio is an indication that the company has liquidity and ability to meet its current liabilities in time. While a low quick ratio show the liquidity position of the firm is not good.

Table 7: Descriptive statistics based on Quick ratio

\begin{tabular}{|l|l|l|l|l|l|l|l|}
\hline Firms & A & B & C & D & E & F & Average \\
\hline Minimum & 1.19 & 0.29 & 0.66 & 0.54 & 0.95 & 0.81 & 0.74 \\
\hline Maximum & 1.75 & 0.55 & 0.93 & 1.59 & 1.10 & 3.02 & 1.49 \\
\hline Mean & 1.43 & 0.46 & 0.77 & 1.21 & 1.03 & 1.38 & 1.04 \\
\hline Std Deviation & 0.49 & 0.24 & 0.27 & 0.90 & 0.11 & 1.77 & 0.63 \\
\hline CV & 24.49 & 51.03 & 35.41 & 74.20 & 10.63 & 128.38 & 55.69 \\
\hline
\end{tabular}

Table 7 shows unsatisfactory mean quick ratio for companies B, C and E, all lower than the average. The mean quick ratio for companies $\mathrm{A}, \mathrm{D}$ and $\mathrm{F}$ are satisfactory since they are higher than the average. The mean quick ratio for $\mathrm{A}, \mathrm{D}, \mathrm{E}$ and $\mathrm{F}$ compared favorably with the ideal ratio of 1:1. The standard deviations for firm $\mathrm{D}$ and $\mathrm{F}$ are higher than the average while for the other companies they are lower than the average. Greater variability in the quick ratio indicates improper management of funds inasmuch as the excess liquidity could have otherwise been used for investment purposes thereby improving the growth of the companies.

Cash and cash equivalents are the most liquid assets. Cash Position Ratio is more accurate test of liquidity than Current Ratio and Quick Asset Ratio.

Table 8:Descriptive statistics based on Cash Position Ratio

\begin{tabular}{|l|l|l|l|l|l|l|l|}
\hline Firms & A & B & C & D & E & F & Average \\
\hline Minimum & 0.0068 & 0.0157 & 0 & 0.2472 & 0 & 0.0293 & 0.050 \\
\hline Maximum & 0.0731 & 0.1691 & 0.0097 & 0.5257 & 0 & 0.0412 & 0.128 \\
\hline Mean & 0.0196 & 0.0660 & 0.0018 & 0.3949 & 0 & 0.0338 & 0.086 \\
\hline Std Deviation & 0.0059 & 0.141 & 0.010 & 0.198 & 0 & 0.01 & 0.070 \\
\hline CV & 302.74 & 203.26 & 279.47 & 50.40 & 0 & 31.8 & 144.611 \\
\hline
\end{tabular}


Table 8 shows mean cash position ratio of firm $\mathrm{E}$ is zero. When cash position ratio is zero or negative, it shows that liquidity is not just poor but also that the firm does not maintain any liquid cash to meet short term obligation. Firm D has a satisfactory ratio which is above the average. The standard deviations for all companies are lower than the average. Greater variability in the cash position ratio indicates improper management of funds inasmuch as the excess liquidity could have otherwise been used for investment purposes thereby enabling the company to continue to grow.

Days of inventory measures the time taken to convert stocks into sales. A lower period indicates efficient management of inventory because the more frequent the stock is sold, the lesser is the amount of money required in financing acquisition of inventory. A higher period indicates inefficient management of inventory, over investment in inventories, sluggish business and poor quality of goods that lead to lower profits as compared to total investment [16].

Table 9: Descriptive statistics based on days of inventory

\begin{tabular}{|l|l|l|l|l|l|l|l|}
\hline Firms & A & B & C & D & E & F & Average \\
\hline Minimum & 121.29 & 79.74 & 73.82 & 74.45 & 47.89 & 162.14 & 93.22 \\
\hline Maximum & 170.36 & 90.71 & 108.04 & 195.03 & 78.60 & 285.15 & 154.65 \\
\hline Mean & 144.8 & 86.46 & 86.06 & 124.50 & 65.72 & 224.91 & 122.05 \\
\hline Std Deviation & 48.10 & 8.70 & 29.07 & 87.02 & 22.04 & 87.01 & 46.99 \\
\hline CV & 33.22 & 10.07 & 33.78 & 69.90 & 33.53 & 38.68 & 36.53 \\
\hline
\end{tabular}

Table 9 show the days of inventory is satisfactory for companies B, C and E since they have days of inventory lower than the average. Days of inventory for $\mathrm{A}, \mathrm{D}$ and $\mathrm{F}$ are more than the average; this indicates inefficient inventory control policy. The standard deviations for firm $\mathrm{F}$ shows more variation than the average. While the standard deviations for the other companies are less variable. Greater variability in the days of inventory indicate improper inventory management policy inasmuch as low inventory indicates unnecessary recurring expense in order to place and receive orders whereas high inventory results in unnecessary blockage of money that could otherwise have been invested.

Days of accounts receivable gives an indication of the efficiency of the credit and collection policy of the firm. It measures the time taken to convert debtors into cash. The lower the period of days of accounts receivable the better; because it means prompt payment by customers [16].

Table 10: Descriptive statistics based on days of accounts receivable

\begin{tabular}{|l|l|l|l|l|l|l|l|}
\hline Firms & A & B & C & D & E & F & Average \\
\hline Minimum & 72.83 & 34.47 & 121.46 & 87.09 & 113.32 & 101.59 & 88.43 \\
\hline Maximum & 189.17 & 84.25 & 165.80 & 141.71 & 186.09 & 137.11 & 150.69 \\
\hline Mean & 142.90 & 61.54 & 136.83 & 126.67 & 130.46 & 121.02 & 119.90 \\
\hline Std Deviation & 102.83 & 43.51 & 35.52 & 44.74 & 60.51 & 25.37 & 52.08 \\
\hline CV & 71.97 & 70.70 & 25.96 & 35.32 & 46.38 & 20.96 & 45.22 \\
\hline
\end{tabular}

It is observed from Table 10 that the average days of accounts receivable as 119.9 days. Above data indicate unsatisfactory days of accounts receivable for all companies except B. The standard deviations companies $\mathrm{A}$ and $\mathrm{E}$ show more variation than the average. While the standard deviations for the other companies are less variable. Greater variability in the days of accounts receivable indicate improper management of funds inasmuch as these funds shall not be available for operations. Moreover, there is a probable increase in the bad debt risk.

Days of accounts payable gives an indication of efficiency of the credit and payment policy of the firm. The higher the credit payment period the longer is the better is the creditors' management whereas shorter the days of accounts payable shows inefficient and poor payment policy that is accountable to decreased current liabilities burden and unsatisfactory liquidity position [16].

Table 11: Descriptive statistics based on days of accounts payable

\begin{tabular}{|l|l|l|l|l|l|l|l|}
\hline Firms & A & B & C & D & E & F & Average \\
\hline Minimum & 90.8 & 42.85 & 92.12 & 48.32 & 67.12 & 155.39 & 82.77 \\
\hline Maximum & 176.36 & 80.94 & 122.68 & 91.10 & 77.97 & 311.96 & 143.50 \\
\hline Mean & 139.55 & 59.12 & 111.43 & 74.88 & 69.78 & 242.07 & 116.11 \\
\hline Std Deviation & 72.48 & 41.39 & 32.60 & 34.77 & 11.17 & 111.65 & 50.68 \\
\hline CV & 51.94 & 70.02 & 29.30 & 46.44 & 16.01 & 46.12 & 43.30 \\
\hline
\end{tabular}

Table 11 shows that the mean days of accounts payable of companies $\mathrm{A}$ and $\mathrm{F}$ are higher than the average which indicates better management of liquidity. The standard deviations for companies $\mathrm{A}$ and $\mathrm{F}$ are higher than the average. High variability indicates inefficient management of the payment policy. 
Cash conversion cycle is a measure of working capital efficiency. The cycle measures the number of days working capital is invested in the operating cycle. Shortening the cash conversion cycle improves the profitability of the firm. On the other hand, the longer the cash conversion cycle, the larger the amount of funds tied in working capital [16].

Table 12: Descriptive statistics based on cash conversion cycle

\begin{tabular}{|l|l|l|l|l|l|l|l|}
\hline Firms & A & B & C & D & E & F & Industry \\
\hline Minimum & 112.17 & 62.84 & 82.82 & 167.04 & 113.32 & 98.47 & 106.11 \\
\hline Maximum & 191.99 & 131.74 & 135.49 & 191.02 & 171.31 & 110.30 & 155.31 \\
\hline Mean & 148.13 & 88.75 & 111.62 & 176.29 & 126.39 & 103.86 & 125.84 \\
\hline Std Deviation. & 67.33 & 56.69 & 50.41 & 17.72 & 48.24 & 9.52 & 41.65 \\
\hline CV & 45.66 & 63.88 & 45.16 & 10.05 & 38.17 & 9.17 & 35.31 \\
\hline
\end{tabular}

Table 12 shows that the average cash conversion cycle is 125.84 days. Above data indicate unsatisfactory cash conversion cycle for companies A, D and E compared to the average. It is satisfactory for B, $\mathrm{C}$ and $\mathrm{F}$ compared to the average. The standard deviations for companies $\mathrm{D}$ and $\mathrm{F}$ are lower than the average. Similarly variability of cash conversion cycle for companies $\mathrm{D}$ and $\mathrm{F}$ are lower than the average.

\section{Correlation analysis}

The strength of the relationship between working capital liquidity and ROA was determined using Pearson correlation. As shown in Table 13 below, there is a positive correlation between quick ratio, current ratio, days of collections and ROA. On the other hand, there is a negative correlation between ROA and days of sales and days of payable. The correlation between days of collection and ROA is statistically insignificant ( $>0.05)$. Table 13 show the correlation between quick ratio and current ratio is is greater than $0.8(r=0.956)$. Also greater than 0.8 is the correlation between inventory turnover and accounts payable turnover $(r=0.849)$. when $r$ is graeter than 0.8 , their may exist the problem of multicollinearity. To eliminate the problem of multicollinearity, four regression models were used; each model has variables that have no collinearity problem.

Table 13: correlation Matrix

\begin{tabular}{|c|c|c|c|c|c|c|}
\hline & 1 & 2 & 3 & 4 & 5 & 6 \\
\hline \multirow{2}{*}{ ROA } & 1 & & & & & \\
\hline & & & & & & \\
\hline \multirow{2}{*}{ CR } & $0.532^{* *}$ & 1 & & & & \\
\hline & 0.000 & & & & & \\
\hline \multirow[b]{2}{*}{$\mathrm{QR}$} & $0.555^{* *}$ & $0.956^{* *}$ & 1 & & & \\
\hline & \begin{tabular}{|l|}
0.000 \\
\end{tabular} & \begin{tabular}{|l|}
0.000 \\
\end{tabular} & & & & \\
\hline \multirow{2}{*}{ ART } & -0.147 & \begin{tabular}{|l|}
0.318 \\
\end{tabular} & $0.463^{* *}$ & 1 & & \\
\hline & \begin{tabular}{|l|}
0.407 \\
\end{tabular} & \begin{tabular}{|l|}
0.067 \\
\end{tabular} & 0.006 & & & \\
\hline \multirow{2}{*}{ INT } & $0.724^{* *}$ & $0.422^{*}$ & $0.440^{* *}$ & 0.151 & 1 & \\
\hline & \begin{tabular}{|l|}
0.000 \\
\end{tabular} & \begin{tabular}{|l|}
0.013 \\
\end{tabular} & \begin{tabular}{|l|l|}
0.009 \\
\end{tabular} & 0.393 & & \\
\hline \multirow{2}{*}{ APT } & $0.636^{* *}$ & 0.308 & $0.440^{* *}$ & $0.402^{*}$ & $0.849^{* *}$ & 1 \\
\hline & \begin{tabular}{|l|}
0.000 \\
\end{tabular} & \begin{tabular}{|l|}
0.077 \\
\end{tabular} & \begin{tabular}{|l|}
0.009 \\
\end{tabular} & 0.018 & 0.000 & \\
\hline
\end{tabular}

$\mathrm{ROA}=$ Return on asset, $\mathrm{CR}=$ current ratio, $\mathrm{QR}=\mathrm{Quick}$ ratio, $\mathrm{ART}=$ accounts receivable turnover, $\mathrm{INT}=$ invetory turnover, APT = accounts payable turnover,

The regression model 1 was as follows.

\section{Regression analysis}

$Y=\beta_{0}+\beta_{1} X_{1}+\beta_{3} X_{3}+\beta_{4} X_{4}+\varepsilon_{i}$

Where; $\mathrm{Y}=$ return on assets

$\mathrm{X}_{1}=$ quick acid ratio

$\mathrm{X}_{3}=$ receivable turnover

$\mathrm{X} 4=$ inventory turnover

$\beta_{0}=$ the return on asset in the absence of any influence by liquidity.

$\beta_{1} \beta_{3}$ and $\beta_{4}$ are the coefficients of liquidity ratios

Table 14: Regression model summary of liquidity ratio against ROA

\begin{tabular}{|c|c|c|c|c|c|}
\hline Model & R & R Square & $\begin{array}{c}\text { Adjusted R } \\
\text { Square }\end{array}$ & $\begin{array}{c}\text { Std. Error of the } \\
\text { Estimate }\end{array}$ & Durbin-Watson \\
\hline 1 & $.878^{\mathrm{a}}$ & .771 & .748 & 13.09639 & 1.434 \\
\hline
\end{tabular}


Table 15: Regression results of liquidity ratio against ROA

\begin{tabular}{|c|c|c|c|c|c|}
\hline Model & Sum of Squares & Df & Mean Square & $\mathbf{F}$ & Sig. \\
\hline Regression & 17335.875 & 3 & 5778.625 & 33.692 & $.000^{\mathrm{b}}$ \\
\hline Residual & 5145.463 & 30 & 171.515 & & \\
\hline Total & 22481.338 & 33 & & & \\
\hline
\end{tabular}

Table 16: Regression coefficients of liquidity ratio against ROA

\begin{tabular}{|c|c|c|c|c|c|c|c|}
\hline \multirow[t]{2}{*}{ Model } & \multicolumn{2}{|c|}{ Unstandardized Coefficients } & \multirow{2}{*}{$\begin{array}{c}\begin{array}{c}\text { Standardized } \\
\text { Coefficients }\end{array} \\
\text { Beta }\end{array}$} & \multirow[t]{2}{*}{$\mathbf{T}$} & \multirow[t]{2}{*}{ Sig. } & \multicolumn{2}{|c|}{ Collinearity Statistics } \\
\hline & B & Std. Error & & & & Tolerance & VIF \\
\hline (Constant) & 27.887 & 8.334 & & 3.346 & .002 & & \\
\hline QR & 25.121 & 5.181 & .527 & 4.848 & .000 & .645 & 1.551 \\
\hline ART & -116.004 & 24.043 & -.477 & -4.825 & .000 & .782 & 1.279 \\
\hline INT & 100.308 & 17.338 & .564 & 5.785 & .000 & .802 & 1.246 \\
\hline
\end{tabular}

$\mathrm{QR}=$ quick ratio, $\mathrm{ART}=$ account receivable turnover, $\mathrm{INT}=$ inventory turnover

The regression model 2 was as follows.

$Y=\beta_{0}+\beta_{2} X_{2}+\beta_{3} X_{3}+\beta_{4} X_{4}+\varepsilon_{i}$

Where; $\mathrm{Y}=$ return on assets

$\mathrm{X}_{2}=$ current ratio

$\mathrm{X}_{3}=$ account receivable turnover

$\mathrm{X} 4$ = inventory turnover

$\beta_{0}=$ the return on asset in the absence of any influence by liquidity.

$\beta_{2}$ to $\beta_{4}$ are the coefficients of liquidity ratios

Table 17: Regression model summary of liquidity ratio against ROA

\begin{tabular}{|c|c|c|c|c|c|}
\hline Model & $\mathbf{R}$ & R Square & $\begin{array}{c}\text { Adjusted R } \\
\text { Square }\end{array}$ & $\begin{array}{c}\text { Std. Error of the } \\
\text { Estimate }\end{array}$ & Durbin-Watson \\
\hline 1 & $.840^{\mathrm{a}}$ & .705 & .676 & 14.85875 & 1.399 \\
\hline
\end{tabular}

Table 18: Regression results of liquidity ratio against ROA

\begin{tabular}{|l|r|r|r|r|r|}
\hline \multicolumn{1}{|c|}{ Model } & \multicolumn{1}{|c|}{ Sum of Squares } & df & Mean Square & \multicolumn{1}{c|}{ F } & Sig. \\
\hline Regression & 15857.864 & 3 & 5285.955 & 23.942 & $.000^{\mathbf{b}}$ \\
Residual & 6623.473 & 30 & 220.782 & & \\
Total & 22481.338 & 33 & & & \\
\hline
\end{tabular}

Table 19: Regression coefficients of liquidity ratio against ROA

\begin{tabular}{|c|c|c|c|c|c|c|c|}
\hline \multirow[t]{2}{*}{ Model } & \multicolumn{2}{|c|}{ Unstandardized Coefficients } & \multirow{2}{*}{$\begin{array}{c}\begin{array}{c}\text { Standardized } \\
\text { Coefficients }\end{array} \\
\text { Beta }\end{array}$} & \multirow[t]{2}{*}{$\mathbf{T}$} & \multirow[t]{2}{*}{ Sig. } & \multicolumn{2}{|c|}{ Collinearity Statistics } \\
\hline & $\mathbf{B}$ & Std. Error & & & & Tolerance & VIF \\
\hline (Constant) & 14.854 & 10.001 & & 1.485 & .148 & & \\
\hline CR & 17.194 & 5.056 & .38 & 3.401 & .002 & .756 & 1.323 \\
\hline ART & -88.459 & 25.447 & -.36 & -3.476 & .002 & .898 & 1.113 \\
\hline INT & 109.491 & 19.439 & .61 & 5.633 & .000 & .822 & 1.217 \\
\hline
\end{tabular}

$\mathrm{CR}=$ current ratio, $\mathrm{ART}=$ account receivable turnover, $\mathrm{INT}=$ inventory turnover

The regression model 3 was as follows.

$$
Y=\beta_{0}+\beta_{1} X_{1}+\beta_{3} X_{3}+\beta_{5} X_{5}+\varepsilon_{i}
$$

Where; $\mathrm{Y}=$ return on assets

$\mathrm{X}_{1}=$ quick acid ratio

$\mathrm{X}_{3}=$ account receivable turnover

$\mathrm{X}_{5}=$ account payable turnover

$\beta_{0}=$ the return on asset in the absence of any influence by liquidity.

$\beta_{1} \beta_{3}$ and $\beta_{5}$ are the coefficients of liquidity ratios 
Table 20: Regression model summary of liquidity ratio against ROA

\begin{tabular}{|c|c|c|c|c|c|}
\hline Model & R & R Square & $\begin{array}{c}\text { Adjusted R } \\
\text { Square }\end{array}$ & $\begin{array}{c}\text { Std. Error of the } \\
\text { Estimate }\end{array}$ & Durbin-Watson \\
\hline 1 & $.915^{\mathrm{a}}$ & .838 & .822 & 11.01489 & 1.737 \\
\hline
\end{tabular}

Table 21: Regression results of liquidity ratio against ROA

\begin{tabular}{|c|l|r|r|r|r|c|}
\hline \multicolumn{2}{|c|}{ Model } & Sum of Squares & df & Mean Square & F & Sig. \\
\hline \multirow{3}{*}{1} & Regression & 18841.501 & 3 & 6280.500 & 51.765 & $.000^{\mathrm{b}}$ \\
\cline { 2 - 7 } & Residual & 3639.837 & 30 & 121.328 & & \\
\cline { 2 - 7 } & Total & 22481.338 & 33 & & & \\
\hline
\end{tabular}

Table 22: Regression coefficients of liquidity ratio against ROA

\begin{tabular}{|c|c|c|c|c|c|c|c|}
\hline \multirow[t]{2}{*}{ Model } & \multicolumn{2}{|c|}{ Unstandardized Coefficients } & \multirow{2}{*}{$\begin{array}{c}\begin{array}{c}\text { Standardized } \\
\text { Coefficients }\end{array} \\
\text { Beta } \\
\end{array}$} & \multirow[t]{2}{*}{$\mathbf{T}$} & \multirow[t]{2}{*}{ Sig. } & \multicolumn{2}{|c|}{ Collinearity Statistics } \\
\hline & B & Std. Error & & & & Tolerance & VIF \\
\hline (Constant) & 42.818 & 6.299 & & 6.797 & .000 & & \\
\hline QR & 27.755 & 4.157 & .583 & 6.676 & .000 & .709 & \\
\hline ART & -165.333 & 20.834 & -.679 & -7.936 & .000 & .736 & 1.3 \\
\hline APT & 101.022 & 13.072 & 653 & 7.728 & .000 & .756 & 1.3 \\
\hline
\end{tabular}

$\mathrm{QR}=$ quick ratio, $\mathrm{ART}=$ account receivable turnover, $\mathrm{APT}=$ accounts payable turnover

The regression model 4 was as follows.

$Y=\beta_{0}+\beta_{2} X_{2}+\beta_{3} X_{3}+\beta_{5} X_{5}+\varepsilon_{i}$

Where; $\mathrm{Y}=$ return on assets

$\mathrm{X}_{2}=$ current ratio

$\mathrm{X}_{3}=$ receivable turnover

$\mathrm{X}_{5}=$ account payable turnover

$\beta_{0}=$ the return on asset in the absence of any influence by liquidity.

$\beta_{2} \beta_{3}$ and $\beta_{5}$ are the coefficients of liquidity ratios

Table 23: Regression model summary of liquidity ratio against ROA

\begin{tabular}{|c|c|c|c|c|c|}
\hline Model & R & R Square & Adjusted R Square & $\begin{array}{c}\text { Std. Error of the } \\
\text { Estimate }\end{array}$ & Durbin-Watson \\
\hline 1 & $.901^{\mathrm{a}}$ & .812 & .793 & 11.87005 & 1.715 \\
\hline
\end{tabular}

Table 24: Regression results of liquidity ratio against ROA

\begin{tabular}{|l|r|r|r|r|r|}
\hline \multicolumn{1}{|c|}{ Model } & Sum of Squares & Df & Mean Square & F & Sig. \\
\hline Regression & 18254.398 & 3 & 6084.799 & 43.186 & $.000^{\mathbf{b}}$ \\
Residual & 4226.939 & 30 & 140.898 & & \\
\hline Total & 22481.338 & 33 & & & \\
\hline
\end{tabular}

Table 25: Regression coefficients of liquidity ratio against ROA

\begin{tabular}{|c|c|c|c|c|c|c|c|}
\hline \multirow[t]{2}{*}{ Model } & \multicolumn{2}{|c|}{ Unstandardized Coefficients } & \multirow{2}{*}{$\begin{array}{c}\begin{array}{c}\text { Standardized } \\
\text { Coefficients }\end{array} \\
\text { Beta } \\
\end{array}$} & \multirow[t]{2}{*}{$\mathbf{T}$} & \multirow[t]{2}{*}{ Sig. } & \multicolumn{2}{|c|}{ Collinearity Statistics } \\
\hline & B & Std. Error & & & & Tolerance & VIF \\
\hline (Constant) & 26.674 & 7.668 & & 3.479 & .002 & & \\
\hline CR & 22.145 & 3.786 & .495 & 5.849 & .000 & .860 & 1.163 \\
\hline ART & -145.064 & 21.589 & -.596 & -6.719 & .000 & .796 & 1.256 \\
\hline APT & 111.727 & 13.678 & .722 & 8.168 & .000 & .802 & 1.246 \\
\hline
\end{tabular}

$\mathrm{CR}=$ current ratio, $\mathrm{ART}=$ account receivable turnover, $\mathrm{APT}=$ accounts payable turnover

In summary, all the four regression models are valid $(\mathrm{p}=0.000)$. The explanatory power of the four model is high with model 3 having the highest $r^{2}(83.8 \%)$. This means the liquidity position of the respondents using model 3 can explain $83.8 \%$ of the ROA while $16.7 \%$ is explained by other factors not in the model. A unit improvement in the independent variable has a positive effect on ROA except for account receivable turnover throughout the four models. Tolerance and VIF were close to one, which denote no multicoliniearity. Finally, autocorrelation was tested using Durbin-Watson statistics. The values for Durbin-Watson statistics were within the acceptable range of zero and four, hence no autocorrelation. 


\section{Suggestion and Recommendations}

For optimal working capital management, the study offers the following suggestions

a) The composition of current asset should be watched so that optimal accounts receivables and inventories are maintained. Tools such as ageing can be used.

b) The ideal current ratio is $2: 1$. The liquidity position of most of the hire purchase companies is unsatisfactory. To avoid poor liquidity position, further investment in the form of liquid resources is required.

c) Suitable policies should be rolled out for improved management of accounts payables. Policies to optimizes accounts payable management should be implemented.

d) The cash conversion cycle should be reduced. It can only be reduced by reducing either days of accounts receivable and days of inventories or increasing the days of payable. An optimal cash conversion cycle will lead to wealth creation for shareholders.

e) Regression results prove that working capital liquidity is the most important determinant of financial performance, hence more finance manager's time should be on working capital components.

\section{Limitation of the study}

This study selected the hire purchase companies who were members of HPRAK. The entire membership was the population and also the sample, which may create some room of error since there were more hire purchase companies which are are not members of HPRAK. This study used financial data and figures supplied by respondents. All the respondents are private companies, which are prone to 'creative accounting' since they are not supervised closely by the government.

\section{References}

[1]. Afza, T, \& Nazir, M. (2009). Impact of aggressive working capital management policy on firm's profitability, The IUP Journal of Applied Finance, 15(8), 20-30

[2]. Pandey, S. \& Jaiswal, V.K. (2011).Effectiveness on profitability: working capital management, SCMS Journal of Indian Management, issue Jan-March

[3]. Van Horne J.C. \& Wachowicz, J. M. (2008). Fundamentals of financial management (13 ${ }^{\text {th }}$ ed.). Prentice Hall, New York.

[4]. Ramachandran, A. \& Janakiraman, M. (2009). The relationship between working capital management efficiency and EBIT, Managing Global Transitions, . 7(1), 61-74

[5]. Dong, H. P.(2010). The relationship between working capital management and Profitability: A Vietnam Case, International Research Journal of Finance and Economics, ISSN 1450-2887, issue 49.Retrieved from http://www.eurojournals.com/finance.htm on 21 st June 2011

[6]. Padachi, K. (2006). Trends in working capital management and its impact on firm's performance: An analysis of Mauritian Small manufacturing companies. International Review of Business Research Papers, 2(2), 45-58.

[7]. Falope, O.I. \& Ajilore, O.T. (2009). Working capital management and corporate profitability: evidence from panel data analysis of selected quoted companies in Nigeria, Research Journal of Business Management, 3(3), 73-84

[8]. Gill, A., Biger, N. \& Mathur, N.(2010). The relationship between working capital management and profitability: Evidence from the United States, Business and Economics Journal, (BEJ), vol.10, Retrieved from http://www.astonjournals.com/manuscripts on 21st June 2011

[9]. Pearce, J.A.\& Robison,R.B.(2003). Strategic management: Formulation, implementation and control, ( $8^{\text {th }}$ ed.), USA: McGraw Hill

[10]. Filbeck, G. \& Krueger, T.(2005). Industry related differences in working capital management, American Journal of Business, 20(3), 11-18

[11]. Alipour, M.(2011).Working capital management and corporate profitability: Evidence from Iran, World Applied Sciences Journal,12(7),1093-1099, ISSM 1818-4952, IDOSI Publications

[12]. Shin, H. \& Soenen, H. (1998). Effeciency of working capital management in the profitability of Hindalco industries limited, Journal of Financial Economics, 6(4), 62-72

[13]. Odipo, M. K. \& Sitati, A., (2011). Evaluation of applicability of Altman's revised model in prediction of financial distress: A case of companies quoted in the Nairobi Stock Exchange, Unpublished journal, University of Nairobi.

[14]. Ross S. A., Westerfield R.W. \& Jaffe. J. (2008). Corporate Finance ( $8^{\text {th }}$ ed.). USA: Mc Graw Hill

[15]. Sayaduzzaman, M.(2006). Working Capital Management: A Study on British American Tobacco Bangladesh Company Ltd. Journal of Nepalese Business Studies III(1)

[16]. Bhunia, A., Khan, I. \& Mukhuti, S. (2011). A study of managing liquidity, Journal of Management Research, 3(2), ISSN 1941899X

[17]. Kariuki, M.I. (2012) An investigation into the extent of application of working capital management techniques in the hire purchase companies in Kenya. Unpublished MBA project, Kenyatta University

[18]. Kothari, C. (2009). Research Methodology:Methods and Techniques (2nd ed.). New Delhi: New age international (P) Limited. 